\title{
Sport strzelecki w kontekście obiektów wojskowych w Polsce międzywojennej (1918-1939) na przykładzie projektów strzelnic z Lublina
}

\author{
Wojciech Kocki \\ Politechnika Lubelska, Wydział Budownictwa i Architektury, Katedra Architektury, \\ Urbanistyki i Planowania Przestrzennego Politechniki Lubelskiej
}

\section{Elżbieta Przesmycka}

Politechnika Wroctawska, Wydziat Architektury, Zakład Konstrukcji i Budownictwa Ogólnego

\begin{abstract}
Streszczenie: Po kilku latach od zakończenia I wojny światowej i coraz lepszej sytuacji kraju zaczęto zacierać granice pomiędzy edukacją i rozwojem kultury fizycznej wojskowej oraz społeczeństwa poprzez wspólne organizacje oraz możliwość korzystania przez coraz większe grupy ludzi wspólnych obiektów sportowych w tym zwłaszcza strzeleckich. Sport w okresie dwudziestolecia międzywojennego pełnił wiele szczególnych wówczas ról w społeczeństwie Polskim. Przy niestabilnej sytuacji politycznej, ekonomicznej i gospodarczej oraz w okresie pierwszych lat okresu międzywojennego gdy próbowano odbudowywać Państwo Polskie po odzyskaniu niepodległości poprzez sport było możliwe utrzymywanie społeczeństwa w coraz lepszej kondycji fizycznej. Taka sytuacja sprzyjała aby wzmacniać obywateli do ewentualnego kolejnego konfliktu zbrojnego. Znikomy budżet i możliwości Rządu finansowanie rozwoju wojska powodowały tworzenie się związków, klubów oraz organizacji paramilitarnych które propagowały kultywowanie tężyzny fizycznej. Strzelectwo miało duże znaczenie w przysposobieniu wojskowym. W okresie zaborów Państwa zaborcze budowały strzelnice, które na początku lat międzywojennych adaptowano na potrzeby kraju. Przykładami strzelnic okresu dwudziestolecia międzywojennego w Lublinie były: Projekt strzelnicy Kolejowego Przysposobienia Wojskowego w Lublinie im. Pułkownika Lisa-Kuli, Projekt strzelnicy małokalibrowej Związku Strzeleckiego w dzielnicy Dziesiątej w Lublinie oraz Projekt Strzelnicy Lubelskiego Towarzystwa Łowieckiego w Lublinie przy ul. Dolnej Panny Marii.
\end{abstract}

Słowa kluczowe: architektura, sport, strzelnice, strzelectwo, budownictwo wojskowe, dwudziestolecie międzywojenne.

\section{Uwarunkowania ogólne sportu w kontekście wojskowym}

Przed rokiem 1939 Państwo Polskie zmagało się z problemami oświatowymi oraz zdrowotnymi. Wychowanie fizyczne oraz sport powiązane było z budowaniem tężyzny fizycznej i militarnymi aspektami rozwoju kraju. Pierwszym organem w kraju, który zajmował się kulturą fizyczną było Ministerstwo Zdrowia Publicznego. Było to spowodowane powiązaniem sportu z problemami zdrowotnymi społeczeństwa. W roku 1919 utworzono dodatkowo Radę do Spraw Wychowania Fizycznego i Kultury Cielesnej, której głównym celem było najlepsze przygotowanie obronne obywateli kraju oraz organizowanie wychowania fizycznego dzieci i młodzieży szkolnej. Wkrótce zauważono, że kształcenie w zakresie kultury fizycznej nie mogło być ograniczane jedynie do grupy rekrutów. Z tego powodu powoływano do życia organizacje paramilitarne nawołujące do przygotowania wojskowego oraz obronności kraju. Przykładami takich organizacji były: Związek Strzelecki „Strzelec", Związek Harcerstwa Polskiego oraz Towarzystwo Gimnastyczne. Rola tych organizacji w szkoleniu wojskowym była ogromna 
ze względu na potrzebę przeszkolenia jak największej liczby osób dla służby wojskowej w okresie niestabilnej sytuacji kraju oraz ryzyka konfliktu militarnego w przyszłości. ${ }^{1}$

Tężyzna fizyczna oraz zdrowe społeczeństwo było traktowane przez Polski rząd jako wizytówka kultury fizycznej. Pozytywnie na rozwój społeczeństwa wpływały również przeszkody w propagowaniu sportu oraz intencji ideologicznych.

Uwarunkowania społeczeństwa wiejskiego ze względu na duże zasoby wolnego czasu pod względem przysposobienia wojskowego i kultywowania wychowania fizycznego była grupa młodociana, która chętnie brała udział w przedsięwzięciach sportowych. Rozwój sportu oraz przysposobienia obronnego na wsi poprzez organizacje paramilitarne był utrudniony i nie przynosił znacznych efektów. Najważniejszymi organizacjami, które działały w części społeczeństwa wiejskiego był Związek Strzelecki „Orlęta” oraz organizacja dotycząca "Strzelczyków" prowadzona przy Korpusie Ochrony Pogranicza.

Rada Wychowania Fizycznego i Przysposobienia Obronnego (PUWFiPW) powołała komisję zajmującą się kulturą fizyczną na wsi. Był to okres w którym próbowano przeprowadzić proces usportowienia mieszkańców terenów wiejskich co było niezwykle trudnym zadaniem.

Istotne zmiany w podejściu do sposobu traktowania konieczności usportowienia mieszkańców wsi wprowadzono w Polsce po maju 1926 roku gdy to marszałek Józef Piłsudski w trakcie przewrotu majowego przejął władzę w II RP. Zaczęto wówczas znacznie intensywniej zwracać uwagę na kształtowanie tężyzny fizycznej wśród społeczeństwa. ${ }^{2}$ Również Józef Piłsudski twierdził, że proces usportowienia wsi mógł znieść jej spokój wewnętrzny co mogłoby wpłynąć negatywnie na jej funkcjonowanie i zatarcie się różnic w społeczeństwie wiejskim oraz miejskim. Dodatkowo potwierdzał opinię, że społeczeństwo wiejskie już poprzez styl funkcjonowania kultywuję tężyznę fizyczną poprzez pracę na roli.

W latach międzywojennych zespoły sportowe na wsiach powstawały przy organizacjach młodzieżowych takich jak: Towarzystwo Gimnastyczne „Sokół”, Polskie Towarzystwo Młodzieżowe, Związek Młodzieży Wiejskiej RP "Wici" oraz Związek Strzelecki "Strzelec".

Wśród organizacji, które w pośredni lub bezpośredni sposób miały związek z militarnym aspektem i przysposobieniem wojskowym była również organizacja Zjednoczenie Strzeleckich bractw Kurkowych Rzeczpospolitej Polskiej - ZSBKRP powołana w 1922 roku powstała w wyniku kooperacji Polskiego Związku Broni Wojskowej oraz Związku Broni Małokalibrowej. W latach 1937-1938 związek posiadał 3000 strzelnic, 400 instruktorów i miał zorganizowanych 781 imprez strzelniczych ${ }^{4}$.

Dla systematyzacji oraz wprowadzenia odznaczeń umiejętności strzeleckich wprowadzono w 1930 roku Odznakę Strzelecką, którą w dwa lata później podzielono na 4 stopnie: Odznaka Strzelca Wyborowego, Odznakę Strzelca III klasy, Odznakę Strzelca II klasy oraz Odznakę Strzelca I klasy. Zdobywano te odznaczenia w Narodowych Zawodach Strzeleckich o Mistrzostwo Polski.

W latach 30 strzeleckie oddziały oraz sekcje były zaopatrywane w sprzęt sportowy coraz częściej i systematyczniej. Rok 1930 był początkiem realizacji nowych obiektów. Zrealizowano wówczas 3 strzelnice małokalibrowe w Hucie Królewskiej. Również w Warszawie zrealizowano strzelnicę w Ogrodzie Saskim.

Ważnym pod względem rozwoju oraz posiadanych obiektów było Pocztowe Przysposobienie Obronne (PPW) które posiadało 43 tory łucznicze i strzelnicze, Na wyposażeniu posiadało 504 sztuki broni długiej, 89 pistoletów i 298 wiatrówek. Najnowocześniejsza wówczas strzelnica znajdowała się we Lwowie. Strzelnica składała się z 10 pawilonów. Siedem z nich było przewidzianych na 79 stanowisk strzelniczych małokalibrowych, karabinowych oraz pistoletowych, dwa obiekty dla myśliwskich strzelań treningowych oraz dla sportów łuczniczych przewidziano oddzielny pawilon ${ }^{5}$.

1 Rafał Szubert, Kultura fizyczna w przemianach wsi polskiej w latach 1944-1956, Studia i Monografie Akademii Wychowania Fizycznego we Wrocławiu, Nr 100, Wydawnictwo AWF, Wrocław, 2010, s. 10-18, 112-145.

2 Mirosław Ponczek, Początki i rozwój polskiej kultury fizycznej na Górnym Śląsku do 1945 roku, Prace Naukowe Akademii im. Jana Długosza w Częstochowie, Seria Kultura Fizyczna z. XII. Nr 1, 2013 s. 3

3 Rafał Szubert, Kultura fizyczna w przemianach wsi polskiej w latach 1944-1956, Studia i Monografie Akademii Wychowania Fizycznego we Wrocławiu, Nr 100, Wydawnictwo AWF, Wrocław, 2010, s. 10-18, 112-145.

4 Józef Czaboćko, Symbioza sztuki ze sportem, Prace Instytutu Kultury Fizycznej nr 26, Zeszyty Naukowe Uniwersytetu Szczecińskiego, 2009. s. 8

5 Józef Czaboćko, Symbioza sztuki ze sportem, Prace Instytutu Kultury Fizycznej nr 26, Zeszyty Naukowe Uniwersytetu Szczecińskiego, 2009. s. 8 
W roku 1936 Towarzystwo Gimnastyczne Sokół działało w 149 sekcjach strzeleckich, a w 1938 roku już zarejestrowanych było 832 kluby sekcyjne zrzeszające 30 tyś. członków.

Od roku 1934 cyklicznie przeprowadzano Centralne Zawody Strzelecko-łucznicze prowadzące do rywalizacji o mistrzostwo PPW. W roku 1936 odbyły się kolejne Mistrzostwa we Lwowie.

\section{Geneza sportu strzeleckiego}

Od momentu odzyskania przez Polskę niepodległości sport odegrał kluczową rolę jako element wychowania obywatelskiego oraz fizycznego społeczeństwa. Było to związane zarówno z procesem umacniania szeregów wojska jak też z podnoszeniem sprawności żołnierzy. W 1938 roku na terenie Rzeczpospolitej było 1130 klubów strzelectwa sportowego zrzeszających 22,6 tys. Członków, 39 klubów szermierczych (1,1 tys. Członków), 200 klubów łuczniczych (6 tys. Członków) ${ }^{6}$. Część zasługi w promowaniu oraz rozwijaniu sportu w szeregach wojskowych zawdzięczano klubom sportowym wśród, których wybijała się Drużyna Sportowa Legia założona w kompanii sztabowej kancelarii w Komendzie Legionów Polskich na Wołyniu. Wówczas istniała w niej jedna sekcja sportowa - piłkarska. ${ }^{7}$ Żołnierze z I oraz III Brygady Legionów organizowali treningi w Wielkopolsce w piłce ręcznej. Grupa ta była internowana z miejscowości Szczypiorno w której powstała ta dyscyplina sportu zwana "szczypiorniakiem". ${ }^{8}$ Kolejnym klubem warszawskim był Wojskowy Klub Sportowy (WKS). Kolejne lata były okresem, w którym powstało coraz więcej takich klubów. Przykładowo był to Wojskowo Cywilny Klub "Kresy" WKS Lublin. Do przewrotu majowego decydującym w kontekście rozwoju sportu i rekreacji był czynnik społeczny. Pomoc materialna Państwa w zakresie inwestycji i finansowania sportu w pierwszej połowie dwudziestolecia była znikoma. Kwota jaką przekazywano na ten cel wynosiła od 500 do 800 dolarów rocznie. Państwo jednak w dużo większym zakresie pomagało pod względem organizacyjnym. W sportach wyczynowych Państwo finansowało podnoszenie kwalifikacji z dwóch źródeł: z Ministerstwa Spraw Wojskowych oraz z Ministerstwa Zdrowia Publicznego. Było to spowodowano podwójnym powiązaniem dyscyplin w zakresie szkoleń wojskowych dyscyplin szermierki, strzelectwa, lekkiej atletyki i jeździectwa.

Jednym z największych sportowych klubów wojskowych był Wojskowy Klub Sportowy Legii Warszawy. Klub dysponował stadionem do piłki nożnej, basenami, kortami tenisowymi, pływalniami oraz wieżą do skoków o wysokości $10 \mathrm{~m}$.

Od 1937 roku sprawami dotyczącymi sportu w Polsce zajmował się Państwowy Urząd Wychowania Fizycznego i Przysposobienia Wojskowego (PUWFiPW) powstały przy Ministerstwie Spraw Wewnętrznych. Do kompetencji tego urzędu należało podejmowanie decyzji dotyczących pomocy organizacyjnych i finansowych dla stowarzyszeń sportowych, W jego kompetencje wchodziły sprawy min. dyskwalifikacji sportowców lub działaczy, rozwiązywania związków oraz zawieszania zarządów związkowych. Organami doradczymi istniejącymi przy Państwowym Urzędzie był Związek Polskich Związków Sportowych i Polski Komitet Olimpijski, którego zadaniem było rozpowszechnianie i uzupełnianie instrukcji rządowych. ${ }^{9}$ Aktem ostatecznie zatwierdzającym całkowite podporządkowanie sportu czynnikowi państwowemu była Konstytucja Sportowa podpisana przez: PKOI, RNWF, ZPZS, PUWFiPW.

O silnym rozwoju zawodów strzelniczych świadczy chociażby fakt wielkiego zainteresowania społeczeństwa tego typu zawodami. Pionierami wśród łuczników Polski międzywojennej byli Apoloniusz Zarychta oraz Mieczysław Fularski. Zawdzięczano im zainicjowanie zawodów o walkę o tytuł Wyborowego Łucznika Polski. Zorganizowano je równolegle do IV Ogólnopolskich Zawodów Strzeleckich, które odbyły się w Katowicach. W roku 1926 wzrost zainteresowania łucznictwem spowodował powołanie Komisji Organizacyjnej Polskiego Związku Łuczników (KOPZŁ). Ewolucja tej dyscypliny w kolejnych latach umożliwiła PZł uzyskanie członkostwa w Naczelnej Rady Strzelectwa w Polsce.

Przełomowym rokiem dla strzelectwa był 1931 ponieważ zorganizowano pierwsze mistrzostwa świata we Lwowie. Powołano na nich Polską Inicjatywę - Międzynarodową Federację Łuczniczą - FITA. Podczas Mistrzostw

6 Mały Rocznik Statystyczny, 1939 rok, hasło związki Sportowe, s. 305, GUS RP

7 Krzysztof Szujecki, Dwudziestolecie Międzywojenne, Tom 15 SPORT, Wydawca Editpresse Polska SA, 2013 s. 34

8 Ibid.

9 Krzysztof Szujecki, Dwudziestolecie Międzywojenne, Tom 15 SPORT, Wydawca Editpresse Polska SA, 2013 s. 35 
wśród uczestników był również Międzynarodowy Kongres Łuczniczy w którym wzięło udział wielu delegatów Szwecji, Czechosłowacji, Francji, Polski, Peru, Włoch, Stanów Zjednoczonych, Estonii, Rumunii, Szwajcarii oraz Węgier. Po igrzyskach zorganizowanych w Antwerpii wycofano ostatecznie łucznictwo z igrzysk olimpijskich w roku 1920. Wśród polskich zawodników i zawodniczek najlepszą była Janina Kurkowska-Spychajowa, która zdobyła wiele pucharów oraz medali zajmując wielokrotnie miejsce na podium jako mistrzyni świata.

\section{Architektura obiektów sportu strzeleckiego oraz łuczniczego na przykładzie miasta Lublin}

Wśród projektów, które realizowano w latach międzywojennych w Lublinie warto zwrócić uwagę na: Projekt strzelnicy Kolejowego Przysposobienia Wojskowego w Lublinie imienia Pułkownika Lisa-Kuli oraz projekt strzelnicy małokalibrowej Związku Strzeleckiego w dzielnicy Dziesiątej w Lublinie oraz na projekt strzelnicy dla Lubelskiego Towarzystwa Łowieckiego lokalizowanej przy ul. Dolnej Panny Marii w Lublinie..

W trakcie realizacji pierwszej strzelnicy w roku 1934 zlokalizowanej przy ul. Nowy Świat w Lublinie, ryc. 1. było wiele istotnych uwag dotyczących istotnych ze względu bezpieczeństwa elementów stanowisk strzelniczych. Uwagi dotyczyły przede wszystkim proporcji osłon oraz niewystarczającej wysokości wału ochronnego. Wśród uwag znalazły się uwarunkowania dotyczące wystarczającej ilości w liczbie 1 osłon lokalizowanych w odległości $15 \mathrm{~m}$ od stanowisk strzeleckich o wysokości 4,35 m z jednym oknem większym o wysokości 1,80 od poziomu terenu. Uwaga ta dotyczyła nieuzasadnienia propozycji wykonania 3 osłon. W uwagach zwracano również szczególnie na jakość wykonania odwodnienia wykopów. Nakazano również podwyższenie wału do wysokości 4,50 m i szerokości 1,00 m oraz spadkach ścian wału w proporcjach 1:1 i 1:5. Szczegółowe przepisy budowy strzelnic znajdowały się wówczas w Instrukcji o strzelnicach szkolnych, które można było nabyć w Księgarni Wojskowej w Warszawie.
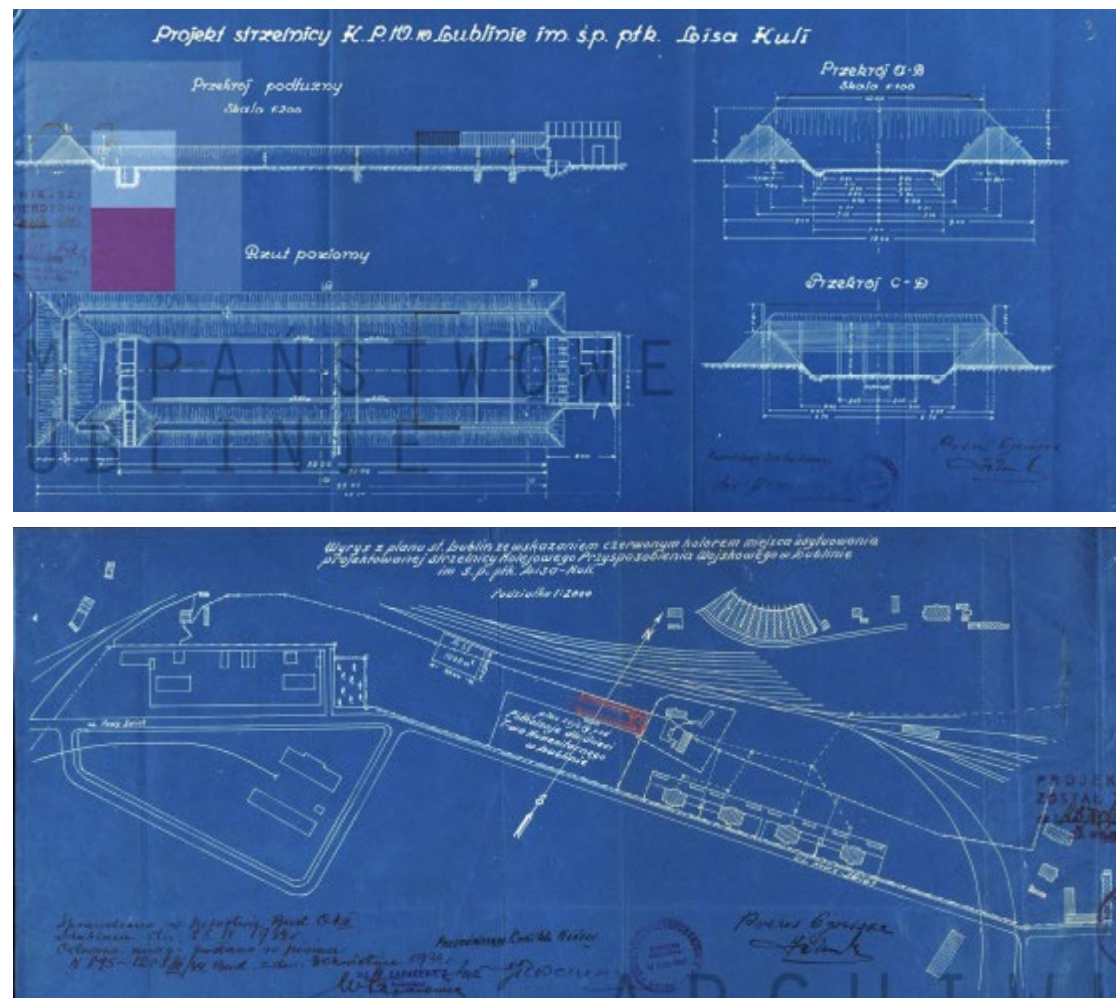

Ryc. 1. Projekt strzelnicy Kolejowego Przysposobienia Wojskowego w Lublinie, (1934 r.) im. Pułkownika Lisa-Kuli, APL, sygnatura 35/403/0/5-5/1520.

Project of the firing range of the Military Appeal in Lublin named after Colonel Lis-Kula (1934), APL, reference number 35/403/0/5-5/1520

Strzelnicę zlokalizowano na terenach kolejowych, za budynkami mieszkalnymi przy ul. Nowy Świat. Obiekt zajmował powierzchnię około $1500 \mathrm{~m}^{2}$. Budynek ze stanowiskami strzelniczymi zaprojektowano w konstrukcji 
drewnianej, jednokondygnacyjnej o pow. $64 \mathrm{~m}^{2}$. Długość całego zamierzenia budowlanego wynosiła 68,20 m a szerokość 18,0 m. Wysokość pawilonu strzelniczego wynosiła około 6,00 m. Obecnie strzelnica nie istnieje oraz nie zachowały się żadne widoczne ślady budynku lub zagospodarowania terenu.

Projekt strzelnicy małokalibrowej Związku Strzeleckiego w dzielnicy Dziesiąta w Lublinie ryc. 2 został sporządzony w roku 1930. Strzelnicę opracowano pod kątem strzelectwa małokalibrowego zgodnie z wówczas obowiązującym okólniku M.S. Wojskowych i Państwowego Urzędu Wychowania Fizycznego i Przysposobienia Obronnego z dnia 28.11.1930 oraz zgodnie z instrukcją O strzelnicach szkolnych wydanych przez M.S. Wojskowych nr Bud. 5/1930 r.

W projekcie założenia strzelniczego zastosowano kanał odwadniający tory strzelnicze o wymiarach $0,40 \times 0,40$ zbierający wodę z terenu strzelnicy i odprowadzał ją na tereny usytuowane niżej. Przesłony chwytające kule budowano z desek 2" jako skrzynie wypełniane żwirem o frakcji 0,20. Wały ochronne projektowano o wysokości 3,60 m od dna. Schrony dla obsługi strzelnicy wznoszono z cegły na zaprawie cementowej.

We wniosku o wydanie decyzji zatwierdzenia projektu wnioskowano również o przyspieszenie formalności związanych z wydzierżawieniem terenu pod budowę obiektu będącego we własności Skarbu Państwa.
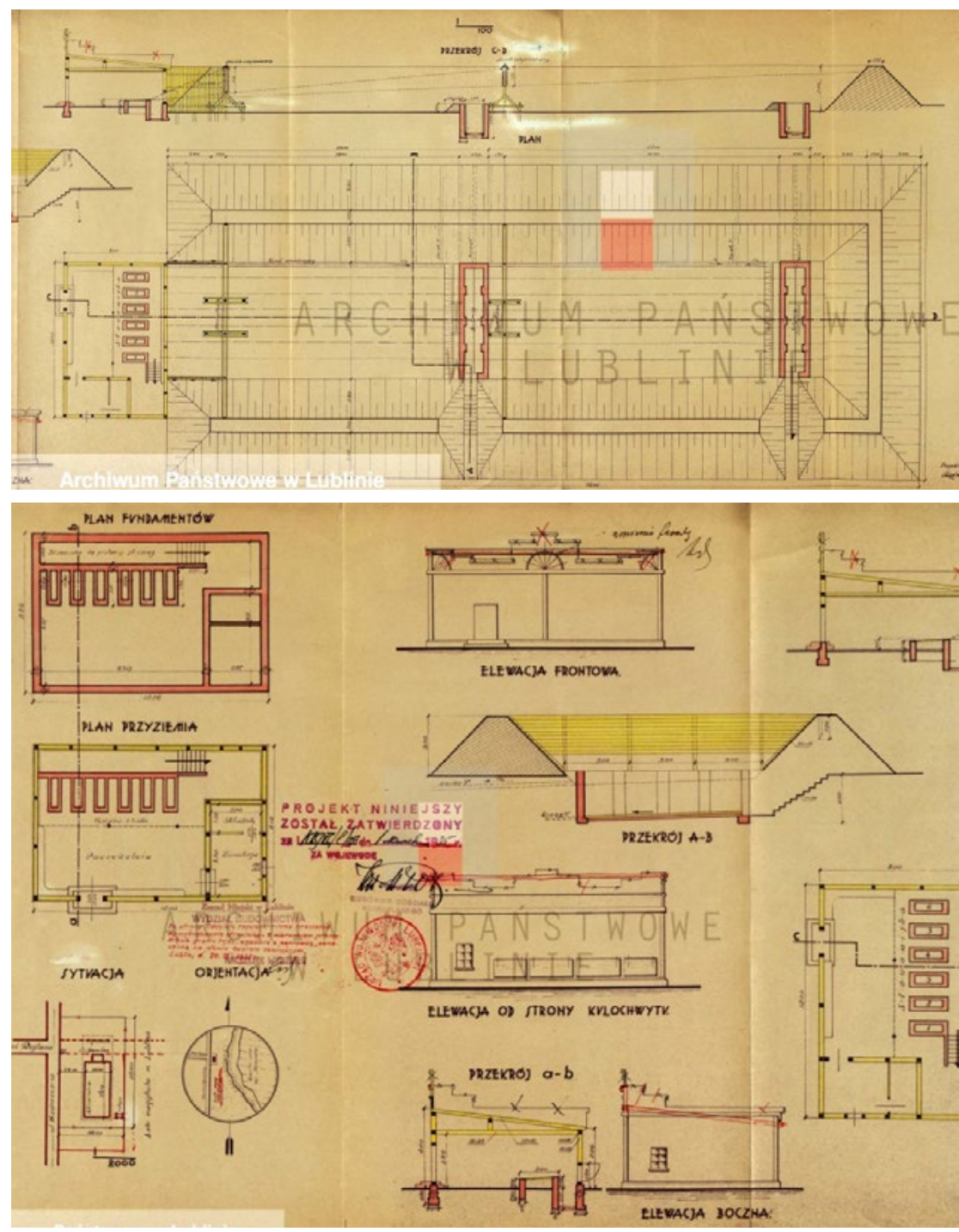

Ryc. 2. Projekt strzelnicy małokalibrowej Związku Strzeleckiego w dzielnicy Dziesiątej w Lublinie, (1934 r.), APL, sygnatura: 35/403/0/5-5/1521.

Project of a small - caliber range of the Związek Strzelecki located in Dziesiąta district in Lublin, (1934), APL, reference number 35/403/0/5-5/1521.

W odpowiedzi na wniosek zawiadomiono o poprawnym zaprojektowaniu obiektu ale zalecono kilka uwag oraz zmian dotyczących usytuowania obiektu, które w złożonym projekcie nie odpowiadało wymaganiom 
instrukcji o strzelnicach szkolnych Bud. 5/1930 r. Nie przestawiono również we wniosku uzgodnienia z Zarządem Miasta lokalizacji obiektu. Zastrzeżono możliwość ćwiczenia wyłącznie strzelectwa z broni małokalibrowej. Względem zmniejszenia kosztów zalecono budowę strzelnicy małokalibrowej o długości $50 \mathrm{~m}$. Zasadniczą część strzelnicy stanowił drewniany pawilon o powierzchni zabudowy około $470 \mathrm{~m}^{2}$ zawierający poczekalnię, stanowiska strzelnicze, kancelarię i składzik sprzętu usytuowanych równolegle do rzeki Czerniejówki. Pawilon strzelniczy zaprojektowano o wymiarach $12,00 \times 8,00 \mathrm{~m}$. Nie zachowały się obecnie żadne ślady świadczące o istnieniu strzelnicy przy skrzyżowaniu ul. Tadeusza Rejtana oraz Nadrzecznej w Lublinie.

Projekt strzelnicy dla Lubelskiego Towarzystwa Łowieckiego lokalizowanej przy ul. Dolnej Panny Marii w Lublinie ryc. 3 jest przykładem wolnostojącego budynku strzelniczego o długości toru $50 \mathrm{~m}$. Budynek zaprojektowano jako obiekt o prostej konstrukcji i rozwiązaniach budowalnych przewidzianych jako tradycyjne murowane elementy oraz część konstrukcji drewnianej. Obiekt zaprojektowano z przekryciem dachu blachą łączoną na rąbek. Pawilon w całości był halą strzelniczą, zadaszoną dachem dwuspadowym ze świetlikami dachowymi. Wymiary części strzelniczej zaprojektowano jako 50,85 m długości oraz 7,20 m szerokości oraz części z pomieszczeniami oraz stanowiskami strzelniczymi jako 1350 m szerokości oraz 6,90 m długości. Doświetlenia części strzelniczej zaprojektowano jako powtarzające się elementy widoczne również w elewacji o długości 3,90 m oraz 0,6 m podziałami słupowymi stanowiącymi konstrukcję wsporczą dla budynku. Wewnątrz przewidziano trzy stanowiska strzelnicze. Wśród pomieszczeń można wyróżnić główna halę, szatnię, pomieszczenie dla dozorcy oraz dla tarczowych. Wysokość wnętrza przewidziano na 5,30 m. Według projektu sytuacyjnego obiekt zlokalizowano na trapezowej działce o pow. około $4500 \mathrm{~m}^{2}$ zlokalizowanego w średniej odległości $35 \mathrm{~m}$ od ulicy Dolnej Panny Marii i otoczenie go ogrodem. Nie zachowały się żadne ślady, które mogłyby wskazywać na dokładne miejsce istnienia strzelnicy.

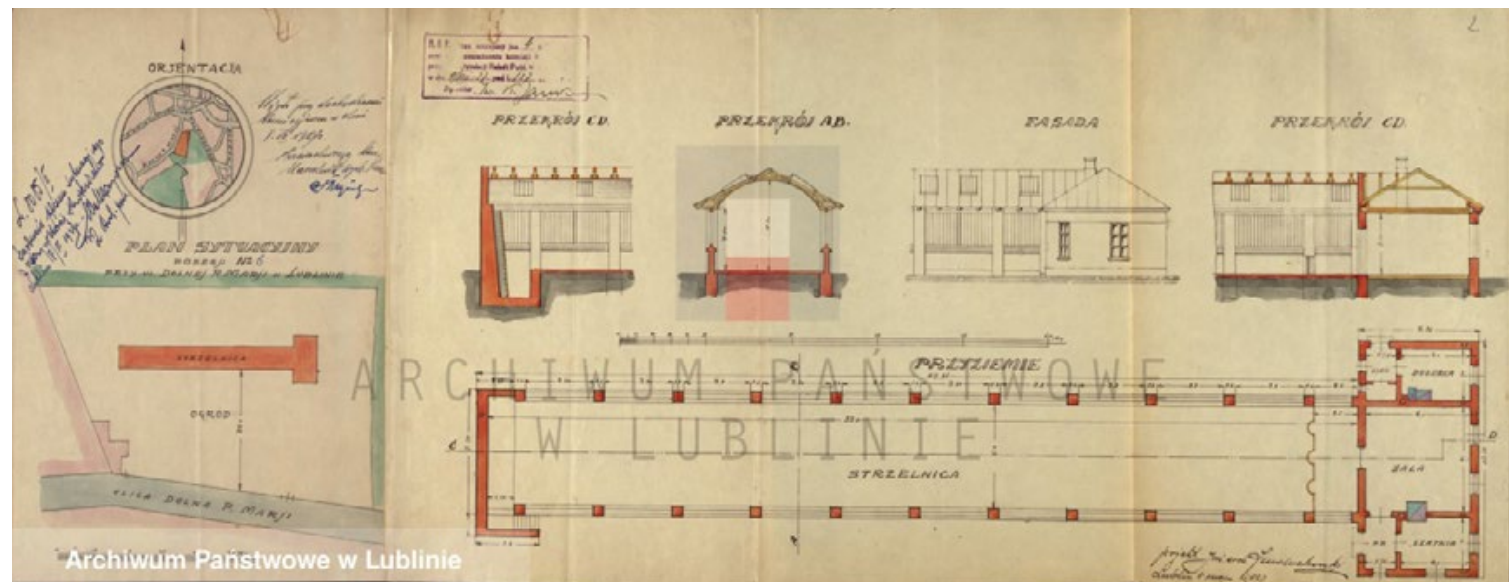

Ryc. 3. Projekt Strzelnicy Lubelskiego Towarzystwa Łowieckiego w Lublinie przy ul. Dolnej Panny Marii (1927 r.), APL, sygnatura 35/403/0/5-5/1519.

Design of shooting range of Lubelskie Towarzystwo Łowieckie in Lublin located near Dolnej Panny Marii street (1927), APL, reference number 35/403/0/5-5/1519.

\section{Wnioski}

Z uwagi na tło polityczne oraz ekonomiczne kraju można stwierdzić, że sport w dwudziestoleciu międzywojennym był jednym z filarów odradzającego się Państwa Polskiego. Nie tylko sport traktowany był jako forma rekreacji oraz rywalizacji na tle ćwiczebnym ale był fundamentem na którym budowany nowe, silne społeczeństwo przygotowane na nadejście w każdej chwili kolejnego konfliktu zbrojnego. Rząd Polski stawiał wysokie wymagania w stosunku do rozwoju militarnego oraz gospodarczego kraju ale zakładane plany były trudne do zrealizowania ze względów finansowych. Dużą rolę odegrały organizacji paramilitarne, stowarzyszenia, kluby oraz indywidualni działacze. Chęć sprostania wymaganiom oraz poziomowi jaki osiągnęły państwa zachodnioeuropejskie Rząd opracowywał stosowane wymogi prawne oraz rozporządzenia a także instrukcje według, 
których należało projektować obiekty strzelnicze. Architektura strzelnic oraz mała architektura towarzysząca tym obiektom była funkcjonalna ale skromna w wyrazie i wystroju. Niewiele elementów budowlanych było projektowanych jako rozwiązania architektoniczne, oryginalne. Zaprezentowane trzy przykłady pokazują głównie techniczne rozwiązania budowlane kształtowane z uwzględnieniem najważniejszych zasad bezpieczeństwa strzelców i otoczenia.

\title{
Literatura
}

[1] Czaboćko J., Symbioza sztuki ze sportem, Prace Instytutu Kultury Fizycznej nr 26, Zeszyty Naukowe Uniwersytetu Szczecińskiego, 2009. s. 8

[2] Mały Rocznik Statystyczny, 1939 rok, hasło związki Sportowe, s. 305, GUS RP

[3] Ponczek M., Początki i rozwój polskiej kultury fizycznej na Górnym Śląsku do 1945 roku, Prace Naukowe Akademii im. Jana Długosza w Częstochowie, Seria Kultura Fizyczna z. XII. Nr 1, 2013 s. 3

[4] Szubert R., Kultura fizyczna w przemianach wsi polskiej w latach 1944-1956, Studia i Monografie Akademii Wychowania Fizycznego we Wrocławiu, $\mathrm{Nr}$ 100, Wydawnictwo AWF, Wrocław, 2010, s. 10-18, 112-145.

[5] Szujecki K., Gawryś Z., Mijakowski K., Dwudziestolecie Międzywojenne, Tom 15 SPORT, Wydawca Editpresse Polska SA, 2013 s. 34-36

\section{Shooting sport in the context of military objects in the middle war period of Poland}

\begin{abstract}
During the interwar period, sport played many special roles in Polish society at that time. In the unstable political and economic situation as well as during the first years of the interwar period when attempts were made to rebuild the Polish State after regaining independence through sport, it was possible to keep the society in increasingly better physical condition. This situation was conducive to strengthening citizens for a possible armed conflict. The Government's limited budget and possibilities for financing the development of the army resulted in the formation of associations, clubs and paramilitary organizations that promoted the cultivation of physical agility. A few years after the end of World War I and the country's increasingly better situation began to blur the boundaries between education and development of military physical culture and society through joint organizations and the possibility of using more common groups of people, especially shooting sports. Shooting as a sport was considered to be key in military terms. Already during the partitions, the partitioners built shooting ranges, which in the early interwar years were adapted to the needs of the country. Examples of shooting ranges from middle war period in Lublin were: Project of shooting range Kolejowego Przysposobienia Wojskowego named of Pułkownika Lisa-Kuli, Project of shooting range Związku Strzeleckiego in Dziesiąta disctrict, Project of shooting range of Lubelskiego Towarzystwa Łowieckiego near Dolnej Panny Marii street
\end{abstract}

Key words: architecture, sport, shooting ranges, shooting, military construction, the interwar period. 